\title{
Milk production responses and rumen fermentation of dairy cows supplemented with summer brassicas
}

\author{
M. Castillo-Umaña ${ }^{1}$, 0. Balocchi ${ }^{1} \odot$, R. Pulido ${ }^{\oplus}$, P. Sepúlveda-Varas ${ }^{2} \odot$, D. Pacheco ${ }^{3} \odot$, \\ S. Muetzel ${ }^{3}$, R. Berthiaume ${ }^{4}$ and J. P. Keim ${ }^{1 \dagger} \oplus$ \\ ${ }^{1}$ Faculty of Agricultural Sciences, Universidad Austral de Chile, 5110566, Independencia 641, Valdivia, Chile; ${ }^{2}$ Faculty of Veterinary Sciences, Universidad Austral de Chile \\ 5110566, Independencia 641, Valdivia, Chile, ${ }^{3}$ Animal Science Group, Grasslands Research Centre, Private Bag 11008, 4442, Palmerston North, New Zealand; ${ }^{4}$ Valacta, \\ Dairy Centre of Expertise, 555 Blvd des Anciens-Combattants, QC H9X 3R4, St Anne de Bellevue, Canada
}

(Received 20 August 2019; Accepted 28 January 2020; First published online 5 March 2020)

Forage brassicas, such as summer turnip (ST; Brassica rapa) and forage rape (FR; Brassica napus), are used as supplementary crops during summer. However, studies with lactating dairy cows fed these forages are limited and report inconsistent productive responses. The aim of this study was to determine dry matter intake, rumen fermentation and milk production responses of dairy cows in mid-lactation supplemented with and without summer ('ST' or 'FR') brassicas. Twelve multiparous lactating dairy cows were randomly allocated to three dietary treatments in a replicated $3 \times 3$ Latin square design balanced for residual effects over three 21-day periods. The control diet consisted of $16.2 \mathrm{~kg}$ DM of grass silage, $2.25 \mathrm{~kg}$ DM of commercial concentrate and $2.25 \mathrm{~kg}$ DM solvent-extracted soybean meal. For the other two dietary treatments, $25 \%$ of the amounts of silage and concentrates were replaced with FR or ST. The inclusion of forage brassicas had no effects on milk production (24.2 kg cow/day average) and composition (average milk fat and protein 43.2 and $33.6 \mathrm{~g} / \mathrm{l}$, respectively). Dry matter intake was $0.98 \mathrm{~kg}$ and $1.12 \mathrm{~kg}$ lower for cows supplemented with FR and ST, respectively, resulting in a greater feed conversion efficiency $(1.35 \mathrm{~kg}$ milk/kg DM for ST and FR v. $1.27 \mathrm{~kg}$ milk/kg DM for the control diet). Intraruminal pH was lower for cows supplemented with ST compared to the control diet; however, it did not decrease below pH 5.8 at any time of the day. After feeding, the concentrations of total short-chain fatty acids (SCFAs) in rumen contents increased with ST supplementation compared to the control diet. Inclusion of FR in the diet increased the molar proportion of acetate $(68.5 \mathrm{mmol} / 100 \mathrm{mmol})$ in total SCFA at the expense of propionate, measured $6 \mathrm{~h}$ after feeding of the forage. The molar proportion of butyric acid was greater with $S T$ and FR supplementation (13.1 and $12 \mathrm{mmol} / 100 \mathrm{mmol}$, respectively) than in control cows. The estimated microbial nitrogen (N) flow was $89.1 \mathrm{~g} /$ day greater when supplementing FR compared to the control diet. Based on the haematological measures, the inclusion of summer brassica forages did not affect the health status of the animals. These results indicate that mid-lactation dairy cows fed brassicas are able to maintain production despite the reduced intake, probably due to improved rumen fermentation and therefore nutrient utilization.

Keywords: forage rape, summer turnips, short-chain fatty acids, microbial protein, feed efficiency

\section{Implications}

The fact that supplementation with summer turnip and forage rape had no effect on milk production and composition is an advantage for dairy farmers, as it may increase farm profitability. The replacement of grass silage and commercial concentrates with brassicas reduces feeding costs and increases profitability. It also contributes to diversification of the forage base for dairy production in temperate grazing systems.

\footnotetext{
† E-mail: juan.keim@uach.cl
}

\section{Introduction}

Summer brassicas are used to supply feed in times of seasonal forage/feed shortage resulting from low rainfall and high temperatures, which reduce pasture quality and growth. The main summer brassica crops are summer turnips (STs) and forage rape (FR; Barry, 2013). They can produce high yields of DM (8 to 15 tons DM/ha) in a relatively short period of time (60 to 120 days), are highly digestible ( 85 to $90 \%$ DM digestibility), have a variable CP content (120 to $200 \mathrm{~g} / \mathrm{kg} \mathrm{DM}$ ) and are characterized by NDF contents below $280 \mathrm{~g} / \mathrm{kg}$ DM (Westwood and Mulcock, 2012). It has been 
observed that brassicas can improve animal performance in terms of milk production, with a response of 0.8 I of milk per $\mathrm{kg}$ of supplemented brassica, and liveweight gain (Moate et al., 1999) and reduce the environmental impact due to lower methane production (2.7 to $7.4 \mathrm{~g} /$ day; Sun et al., 2012) compared to ruminants grazing grass-based pasture diets.

Generally, ST has greater metabolizable energy (ME) contents than FR (3.0 and $2.8 \mathrm{Mcal} / \mathrm{kg} \mathrm{DM}$, respectively), while CP content is greater in FR (160 to $200 \mathrm{~g} / \mathrm{kg} \mathrm{DM}$ ) than in ST (110 to $140 \mathrm{~g} / \mathrm{kg} \mathrm{DM}$, respectively) (Westwood and Mulcock, 2012; Barry, 2013). Recently, Keim et al. (2019) concluded that most of the differences that were observed in terms of chemical composition and degradation kinetics between ST and FR did not affect in vitro fermentation products. However, extrapolations of in vitro results to in vivo situations must be done carefully (Yanez-Ruiz et al., 2016).

Barry (2013) suggested that although brassicas are highly digestible, there are inconsistencies regarding their effects on animal performance. This might be due to detrimental effects of secondary compounds (e.g. S-methyl-cysteine sulphoxide (SMCO), glucosinolates and nitrates) that are present in higher concentrations in brassicas than in other forages. Other factors such as physical limitation of dry matter intake (DMI) due to their high forage water content, inadequate fibre intake for ruminal function and altered fermentation in the rumen may also contribute to the effects on animal performance when these crops are fed (Lambert et al., 1987).

The secondary compounds mentioned above can produce nutritional disorders (Keogh et al., 2009a), might affect rumen fermentation and may produce subclinical alterations that are implicated in reduced voluntary feed intake and the under-performance of brassica-fed livestock (Barry, 2013).

Few experiments have evaluated milk production responses to brassica supplementation (Moate et al., 1998 and 1999) and there is limited published literature reporting the effect of brassica forages on rumen physiology in the dairy cow (Barry, 2013; Keogh et al., 2009a). Most of the experiments have studied ST, which have shown in some cases similar responses to barley supplementation for dairy cows in mid-lactation (Moate et al., 1998), whereas Moate et al. (1999) observed a lower milk production response in cows fed ST compared to concentrate supplementation. Williams et al. (2016) reported increases in milk production from cows supplemented with $F R$, and a reduction in methane intensity and in acetate : propionate ratio (Ac: $\mathbf{P r})$ in the rumen. Nevertheless, there is a lack of studies that compare productive responses and rumen metabolism of dairy cows fed different summer brassicas (Barry, 2013). Thus, we hypothesize that using summer brassicas (ST and FR) to partially replace grass silage and commercial concentrate maintains milk production and composition of mid-lactation dairy cows, without harming metabolic parameters. The aim of this study was to determine DMI, rumen fermentation and milk production responses of mid-lactation dairy cows supplemented with summer (ST or FR) brassicas.

\section{Material and methods}

\section{Animals and experimental design}

The study was conducted at the Experimental Research Station of Universidad Austral de Chile, Valdivia, Chile, between January and March 2017.

Twelve pregnant multiparous lactating Holstein Friesian dairy cows (mean \pm Standard error: $22.7 \pm 0.67 \mathrm{~kg}$ milk/day, $534 \pm 7.5 \mathrm{~kg}$ liveweight and $155 \pm 6.6$ days in milk) were randomly allocated to three dietary treatments in a replicated $3 \times 3$ Latin square design. The experiment lasted 63 days and was divided into three 21-day periods each; the first 14 days of each period consisted in adaptation of the animals to the diets and the last 7 days were used for data collection. Seven days before the first experimental period, the cows were housed in tie-stalls with rubber bedding for adaptation to experimental conditions and received a grass silage and concentrate diet.

\section{Brassica crop production and animal feeding}

Turnip cv. Barkant and FR cv. Spitfire were sown in October and November 2016 in two adjacent 0.5 ha area at a density of 3 and $4 \mathrm{~kg}$ seed/ha, respectively. The crops were sown on two dates with a 20-day interval, in order to offer plant material with a similar stage of maturity throughout the experiment. A fresh allocation of ST was harvested manually daily and soil attached to the roots removed, whereas FR was harvested with a cutter bar mower (Bertolini $140 \mathrm{~L}$, Reggio Emilia, Italy) at $10 \mathrm{~cm}$ above ground level daily.

Cows were divided into three groups according to the dietary treatments (control, ST and FR). For the control diet, $16.2 \mathrm{~kg}$ DM of grass silage, $2.25 \mathrm{~kg}$ DM of commercial concentrate and $2.25 \mathrm{~kg}$ DM soybean meal were offered on a daily basis. For the other two dietary treatments, $25 \%$ of the DM from silage and concentrates were replaced with FR (leaf : stem ratio: $65: 35$ ) or ST (leaf : root ratio: $46: 54$ ). The amount of soybean meal remained constant to keep the three diets isoenergetic and isonitrogenous, which met the ME and protein requirements based on AFRC (1995). Chemical composition of feed ingredients and diets is reported in Table 1. Prior to feeding, all feeds were weighed and offered individually for each cow according to the dietary treatments. Grass silage and soybean meal were offered twice a day at 0800 and $1700 \mathrm{~h}$. Once cows consumed the soybean meal, grass silage was offered. For ST and FR, orts of grass silage were removed at $1100 \mathrm{~h}$ and the total allowed amounts of ST or FR were offered at once for a $5 \mathrm{~h}$ period. Concentrates were offered twice daily during milkings.

\section{Feeds and nutrients intake, milk production and composition}

Feed offered and feed refusals were recorded daily. The content of DM in the feeds was determined on days 1, 3 and 5 of week 3 of each period. Sub-samples of forages (silage, ST and FR) collected once per experimental period, 
Castillo-Umaña, Balocchi, Pulido, Sepúlveda-Varas, Pacheco,Muetzel, Berthiaume and Keim

Table 1 Chemical composition of feed ingredients, diets (control, rape and turnip) and proportion of ingredients offered to mid-lactation dairy cows

\begin{tabular}{|c|c|c|c|c|c|c|c|c|}
\hline & \multirow[b]{2}{*}{ Grass Silage } & \multirow[b]{2}{*}{ Concentrate } & \multirow[b]{2}{*}{ Soybean meal } & \multirow[b]{2}{*}{ Turnips } & \multirow[b]{2}{*}{ Rape } & \multicolumn{3}{|c|}{ Diets } \\
\hline & & & & & & Control & FR & ST \\
\hline DM & $360 \pm 20$ & $893 \pm 3$ & $870 \pm 2$ & $95 \pm 11$ & $117 \pm 10$ & 473 & 388 & 382 \\
\hline Ash & $95 \pm 5$ & $46 \pm 1$ & $71 \pm 1$ & $99 \pm 3$ & $133 \pm 45$ & 87 & 99 & 91 \\
\hline aNDF & $418 \pm 25$ & $334 \pm 3$ & $117 \pm 1$ & $191 \pm 29$ & $217 \pm 19$ & 376 & 332 & 326 \\
\hline ADF & $272 \pm 13$ & $146 \pm 3$ & $42 \pm 1$ & $139 \pm 21$ & $155 \pm 16$ & 234 & 212 & 208 \\
\hline $\mathrm{CP}$ & $177 \pm 11$ & $121 \pm 2$ & $514 \pm 1$ & $145 \pm 21$ & $175 \pm 29$ & 208 & 210 & 203 \\
\hline Lipid & $42 \pm 6$ & $28 \pm 1$ & $23 \pm 1$ & $10 \pm 1$ & $18 \pm 6$ & 38 & 33 & 31 \\
\hline NFC & $268 \pm 27$ & $472 \pm 3$ & $274 \pm 1$ & $551 \pm 32$ & $451 \pm 46$ & 298 & 333 & 358 \\
\hline DOMD & $782 \pm 16$ & $874 \pm 2$ & $905 \pm 1$ & $883 \pm 38$ & $831 \pm 50$ & 803 & 812 & 825 \\
\hline ME & $2.82 \pm 0.06$ & $3.12 \pm 0.28$ & $3.22 \pm 0.14$ & $3.15 \pm 0.13$ & $2.98 \pm 0.17$ & & & \\
\hline \multicolumn{9}{|c|}{ Proportion of ingredients (g/kg DM) } \\
\hline Control & 800 & 145 & 55 & - & - & & & \\
\hline ST & 600 & 95 & 55 & 250 & - & & & \\
\hline FR & 600 & 95 & 55 & - & 250 & & & \\
\hline
\end{tabular}

FR = treatment with a $25 \%$ of forage rape inclusion in the diet; ST = treatment with a $25 \%$ of summer turnip inclusion in the diet; DM = dry matter ( $/ \mathrm{kg}) ;$ aNDF = neutral detergent fibre with a heat stable amylase $(\mathrm{g} / \mathrm{kg} \mathrm{DM}) ; A D F=$ acid detergent fibre $(\mathrm{g} / \mathrm{kg} \mathrm{DM}) ; \mathrm{CP}=$ crude protein $(\mathrm{g} / \mathrm{kg} \mathrm{DM}) ; \mathrm{NFC}=$ non-fibrous carbohydrates $(\mathrm{NFC}=1000-($ ash + lipid + CP + NDF) (g/kg DM); DOMD = digestible organic matter on DM basis (g/kg DM); ME = metabolizable energy (Mcal $/ \mathrm{kg} \mathrm{DM})$.

were freeze-dried and ground through a $1 \mathrm{~mm}$ screen (Wiley Mill, 158; Arthur H. Thomas, Philadelphia, PA, USA) prior to chemical analyses. Leaves and roots of ST and leaves and stems of FR were analysed separately. Leaf: root and leaf: stem ratios were determined for ST and FR, respectively. Dry matter content was determined by weighing before and after drying in a forced-air oven at $105^{\circ} \mathrm{C}$ for $12 \mathrm{~h}$. For each sample, ash and lipids were analysed according to AOAC (1996; method 942.05 and 920.39 for ash and lipids, respectively); nitrogen (N) content was determined by combustion (Leco Model FP-428 Nitrogen Determinator; Leco Corporation, St Joseph, $\mathrm{MI}, \mathrm{USA})$ and was used to calculate $\mathrm{CP}$ content $(\mathrm{N} \times 6.25)$. Neutral detergent fibre was determined as aNDF (Van Soest et al., 1991) using heat stable amylase (Ankom Technology Corp., Macedon, NY, USA) and ADF according to AOAC (1996; method 973.18). Digestible organic matter on DM basis (DOMD) was measured according to Tilley and Terry (1963) and was used to estimate ME by regression (ME $=0.279+$ 0.0325 * DOMD(\%)) (Poff et al., 2011). Non-fibrous carbohydrates (NFCs; g/kg DM) were estimated as follows:

$$
\mathrm{NFC}=1000-(\text { ash }+\mathrm{CP}+\text { lipids }+ \text { aNDF }) .
$$

Cows were milked at 0700 and $1600 \mathrm{~h}$ and milk yield was recorded daily with a flow sensor (MPC580 DeLaval, Tumba, Sweden) during the experimental periods. The average for the final week of each period is reported. Representative milk samples were collected at morning and afternoon milkings for 3 days in the last week of the experimental period for fat, protein, lactose and milk urea analyses by mid-IR spectrophotometry (Foss 4300 Milko-scan; Foss Electric, Hillerod, Denmark).

\section{Rumen fermentation}

Rumen fluid was harvested by stomach tubing (Flora Rumen Scoop; Prof-Products, Guelph, ON, Canada) before (1000 h) and $6 \mathrm{~h}(1600 \mathrm{~h})$ after brassica supplementation on day 6 of week three in each experimental period.

Samples were strained through four layers of cheesecloth. A 10-ml sample was drawn off, mixed with $0.2 \mathrm{ml}$ of $50 \%$ (wt/vol) sulphuric acid and stored at $-20^{\circ} \mathrm{C}$ pending determination of short-chain fatty acid (SCFA) and ammonia $\left(\mathrm{NH}_{3}\right)$ concentrations. Rumen fluid was allowed to thaw for $16 \mathrm{~h}$ at $4^{\circ} \mathrm{C}$ and then centrifuged at $10000 \times \mathrm{g}$ for $10 \mathrm{~min}$ at $4^{\circ} \mathrm{C}$. Six microlitres of supernatant was drawn off and then centrifuged at $10000 \times \mathrm{g}$ for $10 \mathrm{~min}$ at $4^{\circ} \mathrm{C}$. Thawed supernatant of rumen fluid samples was analysed for SCFAs by gas chromatography as described by Tavendale et al. (2005) and for $\mathrm{NH}_{3}$ by the phenol-hypochlorite reaction method (Weatherburn, 1967). Total SCFA (tSCFA) were considered as the sum of acetate, butyrate, proportionate, isobutyrate, valerate, isovalerate and caproate. Minor SCFAs are the sum of isobutyrate, isovalerate, valerate and caproate.

For the whole experiment, rumen $\mathrm{pH}$ was monitored by wireless telemetric pH bolus (eCow, Exeter, UK). Before the experiment started, an internal validation of the $\mathrm{pH}$ bolus was conducted with three cannulated cows. The ruminal samples were collected during 2 days from three sites within the rumen (cranial, ventral and caudal) every $2.5 \mathrm{~h}$. Immediately after collection of rumen fluid, $\mathrm{pH}$ was measured by glass electrode (Model HI98127; Hanna Instruments, Woonsocket, RI, USA). The pH boluses were calibrated before use, programmed to measure rumen $\mathrm{pH}$ at 15 -min intervals and inserted directly into the ventral sac of the rumen of each cow. The data were transmitted wirelessly to a transceiver connected to a cell phone and then transferred to a laptop computer. The $\mathrm{pH}$ data were summarized as mean $\mathrm{pH}$, $\mathrm{pH}$ per hour, time spent with $\mathrm{pH}<6.2$ and $>6.0$, and below $\mathrm{pH} 6.0$.

\section{Urine collection and purine derivative measurements}

Spot urine samples $(20 \mathrm{ml})$ were collected by vulva stimulation (Cosgrove et al., 2017) every 3 h once a day during day 5 
of week 3 in each experimental period, to estimate rumen microbial $\mathrm{N}$ flow based on purine derivatives (PDs, allantoin + uric acid) by HPLC. Samples were acidified with $2 \mathrm{ml}$ sulphuric acid $(10 \% \mathrm{v} / \mathrm{v})$ to maintain $\mathrm{pH}$ below 3 and stored at $-20^{\circ} \mathrm{C}$. Urine samples were thawed, a composited sample per cow was made for each period and analysed for allantoin, uric acid and creatinine by HPLC. Urine volume was estimated using creatinine concentration as a marker (Lindberg, 1989). The amount of microbial purines absorbed (PA, mmol/day) and the PD excreted was estimated from the predictive model proposed by Singh et al. (2007) and the microbial nitrogen flow (MN, g/day) was estimated according to Makkar (2004). Full equations are presented in Supplementary Material S1.

\section{Haematological measures}

Blood samples were collected on day 4 of week 3 in each period, after morning milking. Blood was collected from a coccygeal vessel using two evacuated blood collection tubes (BD Vacutainer; Becton, Dickinson and Company, New Jersey, USA): one containing Ethylenediaminetetraacetic acid $(4 \mathrm{ml})$ and one with no anticoagulant $(9 \mathrm{ml})$. Samples were transported on ice to the haematology laboratory of the Universidad Austral de Chile Teaching Hospital for analysis, where they were centrifuged at $3000 \times \mathbf{g}$ for $10 \mathrm{~min}$ at $25^{\circ} \mathrm{C}$. Whole blood was used for determination of complete blood count; red blood cell (RBC); white blood cell (WBC); haemoglobin concentration; packed red cell volume (PCV); mean corpuscular volume and mean corpuscular haemoglobin concentration. For evaluation of these haematologic parameters, an automated haematology analyzer (KX-21 N; Sysmex, Kobe, Japan) was used. The blood smears were stained with rapid staining (Hemacolor; Merck, Darmstadt, Germany) for a differential WBC count. Heinz-Ehrlich bodies were counted in blood smears prepared on average $5 \mathrm{~h}$ after sampling, using crystal violet staining, and expressed as per cent erythrocytes containing one or more inclusion bodies. Serum samples were stored at $-20^{\circ} \mathrm{C}$ until analysed for urea and gamma-glutamyl transferase (GGT) using a Wiener Metrolab 2300 auto-analyzer (Wiener Lab., Rosario, Argentina) at $37^{\circ} \mathrm{C}$, and triiodothyronine $\left(\mathrm{T}_{3}\right)$ using a validated Elisa Kit (MyBioSource, San Diego, (A, USA).

\section{Statistical Analyses}

The data were analysed using the mixed model procedure of SAS (2006; version 9.4; SAS Institute Inc., Cary, NC, USA) to account for carryover effect according to the following model:

$$
\mathrm{y}_{\mathrm{ijklm}}=\mu+\mathrm{S}_{\mathrm{i}}+\mathrm{A}_{(\mathrm{i}) \mathrm{j}}+\mathrm{P}_{(\mathrm{i}) \mathrm{k}}+\mathrm{T}_{\mathrm{l}}+\mathrm{C}_{\mathrm{m}}+\mathrm{e}_{(\mathrm{ijk}) l},
$$

where $y_{i j k l m}$ is an observation for each dependent variables; $\mu$ is the general mean; $S_{i}$ is the fixed effect of the ith treatment sequence; $A_{(i) j}$ is the random effect of the jth cow in the ith sequence; $P_{(i) k}$ is the fixed effect of the $k$ th period; $T_{1}$ is the fixed effect of the th treatment; $C_{m}$ is the fixed carryover effect from the previous period $(C=0$, if period $=1)$ and $\mathrm{e}_{(\mathrm{ijk}) !}$ is the random error. If carryover effects were not detected, a simplified model for a replicated Latin square was used:

$$
\mathrm{y}_{\mathrm{ijklm}}=\mu+\mathrm{S}_{\mathrm{i}}+\mathrm{A}_{(\mathrm{i}) \mathrm{j}}+\mathrm{P}_{(\mathrm{i}) \mathrm{k}}+\mathrm{T}_{\mid}+\mathrm{e}_{(\mathrm{ijk}) l}
$$

where $y_{i j k l m}$ is the observation for dependent variables; $\mu$ is the general mean; $S_{i}$ is the random effect of the ith square; $\mathrm{A}_{(\mathrm{i}) \mathrm{j}}$ is the random effect of the $j$ th cow in the ith square; $\mathrm{P}_{(i) \mathrm{k}}$ is the fixed effect of the $k$ th period; $T_{\text {, }}$ is the fixed effect of the $/$ th treatment and $\mathrm{e}_{(\mathrm{ijk}) \mid}$ is the random error. The interaction of treatment and period was tested and was determined to be not significant $(P>0.05)$. As a result, this interaction was removed from the model. Data for DMl, milk yield, milk composition, microbial $\mathrm{N}$ and haematological measures were summarized by day. For haematological measures, three tubes were not reported by the laboratory due to coagulation of samples, and therefore different standard errors are reported for each treatment. Data for SCFA, $\mathrm{NH}_{3}$ and $\mathrm{pH}$ were analysed with the same model but including sampling time or hour as a repeated measurement and the interaction of treatment and repeated measurement, with cow as a subject. The estimation method was REML and the df method was Kenward-Roger. The variance-covariance structure that yielded the lowest corrected Akaike information criterion was compound symmetry and selected for the final model. Values reported are least squares means and associated standard errors of the mean. Statistical significance was declared at $P \leq 0.05$ and trends at $0.05<P \leq 0.10$. The PDIFF command, incorporating the Tukey-Kramer adjustment for multiple pairwise comparisons of treatment means, was used (Supplementary Material S2).

\section{Results}

Feed and nutrient intake, milk production and composition Cows supplemented with either ST or FR had a lower DMI $(P<0.001)$ compared to those fed the control diet, basically due to the lower silage $(-3.56 \mathrm{~kg} /$ day $)$ and supplement $(-0.73 \mathrm{~kg} /$ day $)$ intake that was not completely compensated by the ingestion of brassica (3.18 kg/day) (Table 2). Among brassica-supplemented cows, ST intake tended $(P=0.09)$ to be greater $(+0.18 \mathrm{~kg} /$ day $)$ compared to FR.

No difference in $C P$ intake was observed $(P=0.499)$, whereas cows supplemented with either ST or FR had lower lipid, aNDF and ADF intakes $(P<0.001)$. Cows supplemented with ST increased their NFC intake by $0.41 \mathrm{~kg} /$ day compared to the control treatment $(P=0.003)$.

Milk production and composition were not affected by brassica supplementation $(P>0.05)$. This resulted in a greater feed conversion efficiency for cows supplemented with ST or FR compared to the control diet $(+0.08 \mathrm{~kg}$ milk/kg DM; $P=0.015)$.

\section{Rumen $\mathrm{pH}$ and fermentation}

Significant interactions among diet and time of sampling were observed for ISCFA, the relative molar proportion of each 
Castillo-Umaña, Balocchi, Pulido, Sepúlveda-Varas, Pacheco,Muetzel, Berthiaume and Keim

Table 2 Feeds and nutrient intake, and milk yield composition of cows supplemented with turnip or rape

\begin{tabular}{|c|c|c|c|c|c|}
\hline & Control & FR & ST & SEM & $P$-values \\
\hline \multicolumn{6}{|l|}{ Feeds intake (kg DM/day) } \\
\hline Total & $19.00^{\mathrm{a}}$ & $18.02^{b}$ & $17.88^{b}$ & 0.46 & 0.0001 \\
\hline Brassica & - & 3.09 & 3.27 & 0.19 & 0.090 \\
\hline Silage & $14.97^{\mathrm{a}}$ & $11.53^{b}$ & $11.29^{b}$ & 0.29 & $<0.001$ \\
\hline Supplement & $4.09^{\mathrm{a}}$ & $3.40^{\mathrm{b}}$ & $3.32^{\mathrm{b}}$ & 0.13 & $<0.001$ \\
\hline \multicolumn{6}{|l|}{ Nutrient intake $(\mathrm{kg} / \text { day })^{1}$} \\
\hline $\mathrm{CP}$ & 3.65 & 3.84 & 3.71 & 0.14 & 0.499 \\
\hline aNDF & $7.20^{\mathrm{a}}$ & $6.13^{b}$ & $6.00^{\mathrm{b}}$ & 0.15 & $<0.001$ \\
\hline ADF & $4.48^{\mathrm{a}}$ & $3.86^{\mathrm{b}}$ & $3.79^{b}$ & 0.09 & $<0.001$ \\
\hline Lipid & $0.73^{\mathrm{a}}$ & $0.62^{b}$ & $0.59^{b}$ & 0.01 & $<0.001$ \\
\hline NFC & $5.54^{b}$ & $5.71^{\mathrm{ab}}$ & $5.95^{a}$ & 0.07 & 0.003 \\
\hline ME (Mcal/day) & 54.9 & 53.1 & 52.9 & 2.8 & 0.099 \\
\hline Milk production (kg/day) & 24.2 & 24.3 & 24.1 & 0.78 & 0.936 \\
\hline Fat-corrected milk (kg/day) & 25.2 & 25.8 & 25.2 & 0.90 & 0.663 \\
\hline Energy-corrected milk (kg/day) & 26.8 & 27.4 & 27.0 & 0.88 & 0.685 \\
\hline \multicolumn{6}{|l|}{ Milk composition $(\mathrm{g} / \mathrm{kg})$} \\
\hline Fat & 42.8 & 44.1 & 42.8 & 1.40 & 0.538 \\
\hline $\mathrm{CP}$ & 33.1 & 33.6 & 34.2 & 0.80 & 0.320 \\
\hline Lactose & 48.7 & 48.8 & 48.4 & 0.30 & 0.392 \\
\hline \multicolumn{6}{|l|}{ Milk output (g/day) } \\
\hline Fat & 1033 & 1067 & 1033 & 40 & 0.619 \\
\hline $\mathrm{CP}$ & 799 & 815 & 827 & 20 & 0.308 \\
\hline MY : DMI (kg milk/kg DM) & $1.27^{\mathrm{b}}$ & $1.35^{\mathrm{a}}$ & $1.35^{\mathrm{a}}$ & 0.04 & 0.015 \\
\hline
\end{tabular}

$F R=$ treatment with a $25 \%$ of forage rape inclusion in the diet; ST = treatment with a $25 \%$ of summer turnip inclusion in the diet; aNDF = neutral detergent fibre with a heat stable amylase; NFC = non-fibrous carbohydrates; $M E=$ metabolizable energy $(\mathrm{ME}=0.279+0.0325 * \mathrm{DOMD}(\%))^{2}$; fat-corrected milk $=0.4 \times \mathrm{kg}$ milk $+15 \times \mathrm{kg}$ fat; energy-corrected milk $=(12.82 \times \mathrm{kg}$ fat $)+$ $(7.13 \times \mathrm{kg}$ protein $)+(0.323 \times \mathrm{kg}$ milk); $\mathrm{MY}: \mathrm{DMI}=$ feed conversion efficiency (milk yield per unit of dry matter intake); SEM $=$ standard error of the mean; means within a row with different superscripts differ $(P<0.05)$; DOMD $=$ digestible organic matter on DM basis.

${ }^{1}$ Unless stated.

Table 3 Effect of diet and sampling time on total short-chain fatty acids (tSCFA) and ammonia $\left(\mathrm{NH}_{3}\right)$ concentrations, and in the molar proportions of individual SCFA in the rumen fluid of cows supplemented or not with turnip or rape

\begin{tabular}{|c|c|c|c|c|c|c|c|c|c|c|}
\hline & \multicolumn{3}{|c|}{ Before feeding } & \multicolumn{3}{|c|}{ After feeding } & \multirow[b]{2}{*}{ SEM } & \multicolumn{3}{|c|}{$P$-values } \\
\hline & Control & FR & ST & Control & FR & ST & & Diet & Time & $D^{*} T$ \\
\hline tSCFAs (mmol/l) & $100.0^{\mathrm{ab}}$ & $98.7^{\mathrm{ab}}$ & $101.2^{\mathrm{a}}$ & $83.3^{c}$ & $85.3^{b c}$ & $97.1^{\mathrm{ab}}$ & 3.19 & 0.020 & $<0.001$ & 0.014 \\
\hline \multicolumn{11}{|c|}{ SCFAs $(\mathrm{mol} / 100 \mathrm{~mol})$} \\
\hline Acetate & $64.8^{\mathrm{b}}$ & $64.4^{b}$ & $65.2^{b}$ & $66.3^{b}$ & $68.6^{\mathrm{a}}$ & $66.1^{\mathrm{b}}$ & 0.48 & 0.129 & $<0.001$ & 0.004 \\
\hline Propionate & $18.9^{\mathrm{a}}$ & $18.1^{\mathrm{ab}}$ & $17.6^{\mathrm{b}}$ & $17.7^{\mathrm{ab}}$ & $16.0^{c}$ & $18.0^{\mathrm{ab}}$ & 0.33 & $<0.001$ & $<0.001$ & 0.001 \\
\hline Butyrate & $11.6^{\mathrm{b}}$ & $12.7^{\mathrm{ab}}$ & $12.7^{\mathrm{ab}}$ & $11.9^{b}$ & $12.7^{\mathrm{ab}}$ & $13.5^{\mathrm{a}}$ & 0.32 & $<0.001$ & 0.151 & 0.045 \\
\hline Isobutyrate & $1.05^{\mathrm{a}}$ & $1.09^{\mathrm{a}}$ & $1.06^{\mathrm{a}}$ & $0.95^{\mathrm{b}}$ & $0.69^{c}$ & $0.54^{\mathrm{d}}$ & 0.03 & $<0.001$ & $<0.001$ & $<0.001$ \\
\hline Valerate & $1.52^{\mathrm{ab}}$ & $1.59^{\mathrm{a}}$ & $1.50^{\mathrm{ab}}$ & $1.35^{\mathrm{b}}$ & $1.02^{c}$ & $1.03^{c}$ & 0.06 & 0.011 & $<0.001$ & 0.002 \\
\hline Isovalerate & $1.53^{\mathrm{a}}$ & $1.54^{\mathrm{a}}$ & $1.41^{\mathrm{ab}}$ & $1.22^{b}$ & $0.71^{\mathrm{C}}$ & $0.52^{c}$ & 0.06 & $<0.001$ & $<0.001$ & $<0.001$ \\
\hline Caproate & $0.52^{\mathrm{ab}}$ & $0.59^{a}$ & $0.55^{\mathrm{ab}}$ & $0.47^{b c}$ & $0.30^{d}$ & $0.37^{\mathrm{cd}}$ & 0.02 & 0.123 & $<0.001$ & 0.001 \\
\hline mSCFA & $4.64^{\mathrm{a}}$ & $4.82^{\mathrm{a}}$ & $4.52^{\mathrm{ab}}$ & $3.99^{b}$ & $2.73^{c}$ & $2.47^{c}$ & 1.30 & $<0.001$ & $<0.001$ & $<.0001$ \\
\hline$A c: \operatorname{Pr}$ & $3.44^{b}$ & $3.57^{b}$ & $3.71^{b}$ & $3.77^{\mathrm{b}}$ & $4.30^{\mathrm{a}}$ & $3.71^{b}$ & 0.09 & $<0.001$ & $<0.001$ & 0.0002 \\
\hline $\mathrm{NH}_{3}(\mathrm{mmol} / \mathrm{l})$ & $10.1^{\mathrm{ab}}$ & $11.0^{\mathrm{a}}$ & $8.3^{b}$ & $7.4^{\mathrm{b}}$ & $3.8^{c}$ & $2.7^{c}$ & 0.55 & $<0.001$ & $<0.001$ & 0.0005 \\
\hline
\end{tabular}

$\mathrm{FR}=$ treatment with a $25 \%$ of forage rape inclusion in the diet; ST = treatment with a $25 \%$ of summer turnip inclusion in the diet; tSCFA, total short-chain fatty acids (acetate + butyrate + propionate + isobutyrate + isovalerate + valerate + caproate; mmol/l); mSCFA, minor short-chain fatty acids (isobutyrate + isovalerate + valerate + caproate) $(\mathrm{mol} / 100 \mathrm{~mol}) ; \mathrm{Ac}: \mathrm{Pr}=$ acetate : propionate ratio; $\mathrm{NH}_{3}=$ ammonia $(\mathrm{mmol} / \mathrm{l}) ; \mathrm{SEM}=$ standard error of the mean for 'diet ${ }^{*}$ time of the day' interaction; $D^{*} T=$ interaction between diet and time of the day; means within a row with different superscripts differ $(P<0.05)$.

SCFA in tSCFA and $\mathrm{NH}_{3}$ concentrations $(P<0.05$; Table 3). Total SCFA concentration and butyrate molar proportion were similar among diets prior to brassica supplementation. However, $6 \mathrm{~h}$ after supplementation, the rumen fluid of cows supplemented with ST had greater concentrations of ISCFA and butyrate compared to that from cows fed the control diet. Acetate molar proportion was similar among diets before brassica supplementation, whereas after $6 \mathrm{~h}$ it was greater 
Table 4 Effect of rape and turnip supplementation on rumen $\mathrm{pH}$, urinary purine derivative (PD) excretion and blood and milk urea concentrations of mid-lactation dairy cows.

\begin{tabular}{lccccr}
\hline \hline & Control & FR & ST & SEM & $P$-values \\
\hline Mean rumen pH & $6.32^{\mathrm{a}}$ & $6.30^{\mathrm{a}}$ & $6.23^{\mathrm{b}}$ & 0.035 & $<0.001$ \\
$\mathrm{pH}<6.2$ and $>6.0$ (min/day) & 267.4 & 367.4 & 418.9 & 85.98 & 0.097 \\
$\mathrm{pH}<6.0$ (min/day) & 49.7 & 100.9 & 257.5 & 71.51 & 0.099 \\
Urinary PD excretion (mmol/day) & & & & & \\
$\quad$ Allantoin & $291.0^{\mathrm{b}}$ & $393.5^{\mathrm{a}}$ & $359.7^{\mathrm{a}}$ & 16.6 & $<0.001$ \\
$\quad$ Uric acid & $7.3^{\mathrm{b}}$ & $19.7^{\mathrm{a}}$ & $18.6^{\mathrm{ab}}$ & 3.3 & 0.022 \\
$\quad$ Total PD excretion & $264.7^{\mathrm{b}}$ & $368.7^{\mathrm{a}}$ & $314.4^{\mathrm{ab}}$ & 17.5 & 0.002 \\
Microbial N flow (g/day) & $189.1^{\mathrm{b}}$ & $278.3^{\mathrm{a}}$ & $231.8^{\mathrm{ab}}$ & 14.9 & 0.002 \\
Milk urea (mg/dl) & 31.4 & 33.0 & 34.8 & 1.6 & 0.245 \\
Blood urea (mg/dl) & 30.7 & 27.4 & 29.1 & 1.9 & 0.228 \\
\hline \hline
\end{tabular}

$\mathrm{FR}=$ treatment with a $25 \%$ of forage rape inclusion in the diet; ST = treatment with a $25 \%$ of summer turnip inclusion in the diet; $\mathrm{SEM}=$ standard error of the mean; means within a row with different superscripts differ $(P<0.05)$.

in the rumen of cows supplemented with FR. Meanwhile, propionate molar proportion was lower in the rumen of cows fed ST prior to brassica feeding but lowest in cows fed FR after feeding of the crop. The molar proportions of minor SCFA and $\mathrm{NH}_{3}$ concentration were similar among diets prior to brassica supplementation, but $6 \mathrm{~h}$ after supplementation a significant reduction on minor SCFA and $\mathrm{NH}_{3}$ was observed with either FR or ST supplementation. Finally, Ac: Pr was only increased with FR supplementation.

The daily mean of rumen $\mathrm{pH}$ was lower (6.23) for cows supplemented with ST compared to the control and FR diets (6.32 and 6.30, respectively; Table 4) and remained below 6.2 for 143 and 110 more min compared to control and FR diets, respectively. A significant interaction was observed for diet and time of the day (Figure 1). Rumen $\mathrm{pH}$ followed a similar pattern for all treatments, except after p.m. (1600 h) milking: for the control diet, the rumen $\mathrm{pH}$ dropped from 6.38 to 6.14 and then remained relatively constant until $2000 \mathrm{~h}$, when it started to increase. For FR and ST diets, the rumen $\mathrm{pH}$ dropped to 5.96 after p.m. milking and then increased.

\section{Urinary purine derivatives, milk and blood urea and} haematological measures

Daily urinary excretion of allantoin was increased with ST and FR supplementation $(P<0.001)$, whereas uric acid and PD excretion were greater for cows fed FR than for cows fed the control diet, which resulted in a greater estimated $\mathrm{MN}$ $(+89 \mathrm{~g} /$ day; $P=0.002)$. Blood and milk urea were not affected by brassica supplementation $(P>0.05)$ (Table 4).

No differences for any of the haematological values were observed $(P>0.05)$. No Heinz-Ehrlich bodies were detected for any of the dietary treatments. Also, GGT and $T_{3}$ were not affected by either FR or summer ST supplementation (Table 5).

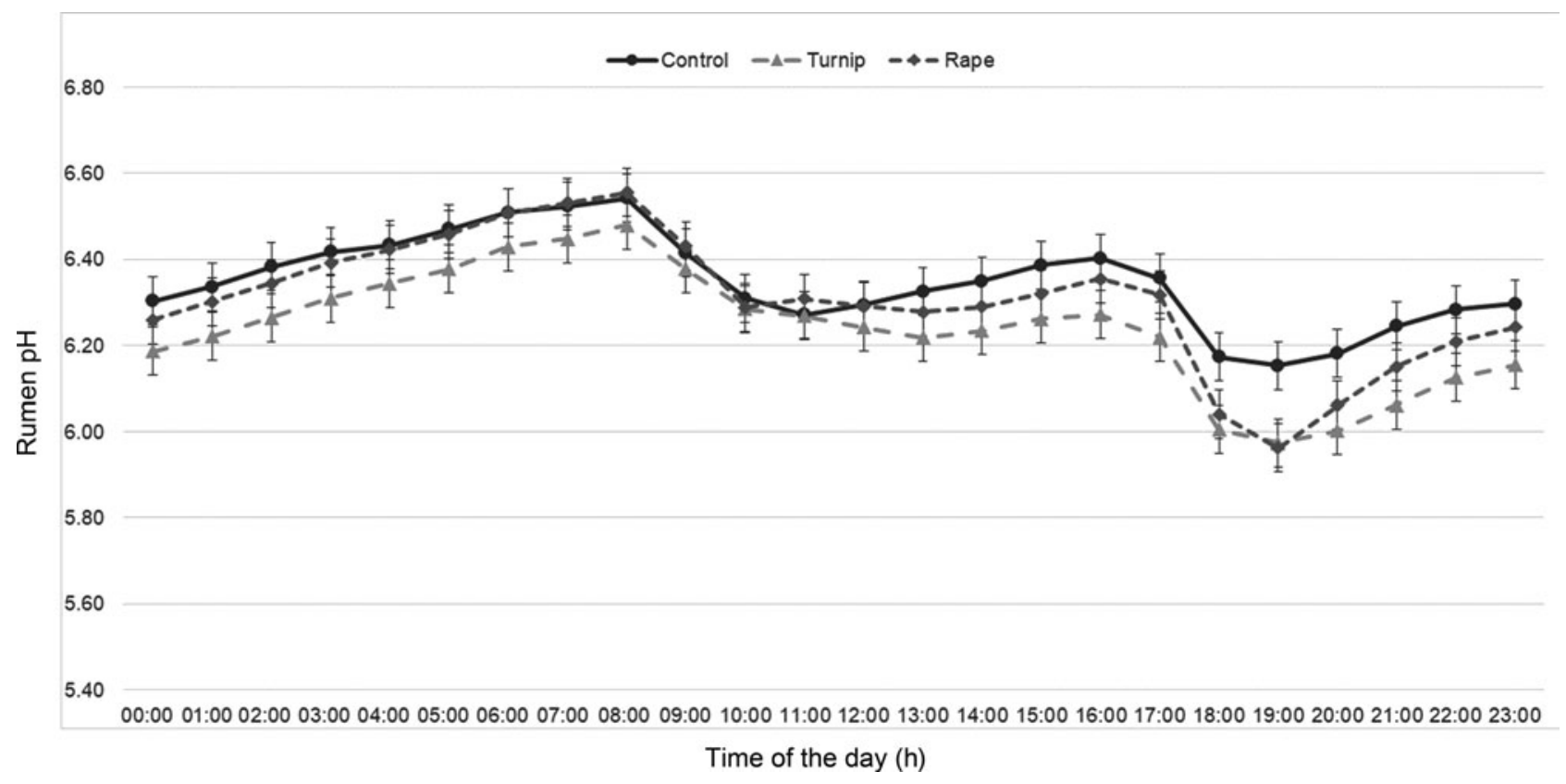

Figure 1 Effect of supplementation with turnips or rape on diurnal variation of rumen $\mathrm{pH}$ of mid-lactation dairy cows. 
Castillo-Umaña, Balocchi, Pulido, Sepúlveda-Varas, Pacheco,Muetzel, Berthiaume and Keim

Table 5 Effect of rape and turnip supplementation in the diet of lactating cows on blood health parameters (least square mean values \pm standard error of the mean)

\begin{tabular}{|c|c|c|c|c|}
\hline & \multicolumn{4}{|c|}{ Treatment } \\
\hline & Control & FR & ST & $P$-values \\
\hline PCV (\%) & $28.8 \pm 0.5$ & $28.8 \pm 0.5$ & $28.9 \pm 0.5$ & 0.992 \\
\hline Haemoglobin $(\mathrm{g} / \mathrm{l})$ & $90.2 \pm 1.9$ & $88.5 \pm 1.9$ & $89.6 \pm 2.1$ & 0.525 \\
\hline $\mathrm{RBC}\left(\mathrm{x} 10^{6} / \mu \mathrm{l}\right)$ & $6.0 \pm 0.2$ & $6.0 \pm 0.2$ & $6.1 \pm 0.2$ & 0.710 \\
\hline 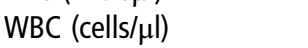 & $7971 \pm 723$ & $8556 \pm 757$ & $8609 \pm 870$ & 0.781 \\
\hline MCV (fL) & $47.6 \pm 1.3$ & $47.8 \pm 1.3$ & $47.8 \pm 1.3$ & 0.928 \\
\hline $\mathrm{MCHC}(\mathrm{g} / \mathrm{l})$ & $313.5 \pm 4.0$ & $307.2 \pm 4.1$ & $308.5 \pm 4.5$ & 0.218 \\
\hline Eosinophils $(\mathrm{n} / \mu \mathrm{l})$ & $709.5 \pm 203$ & $940.7 \pm 207$ & $734.2 \pm 223$ & 0.428 \\
\hline Neutrophils (cells/ $\mu \mathrm{l})$ & $3472 \pm 693$ & $4094 \pm 718$ & $4381 \pm 797$ & 0.568 \\
\hline Lymphocytes (cells/ul) & $2885 \pm 334$ & $3240 \pm 345$ & $3240 \pm 383$ & 0.527 \\
\hline Monocytes (cells/ $\mu l)$ & $351.6 \pm 62$ & $335.6 \pm 65$ & $446.9 \pm 75$ & 0.510 \\
\hline GGT (U/L) & $97.0 \pm 32.4$ & $132.47 \pm 32.4$ & $94.8 \pm 32.36$ & 0.320 \\
\hline $\mathrm{T}_{3}(\mathrm{nmol} / \mathrm{l})$ & $2.52 \pm 0.52$ & $2.25 \pm 0.53$ & $2.50 \pm 0.54$ & 0.705 \\
\hline Heinz-Ehrlich bodies (\%) & ND & ND & ND & - \\
\hline
\end{tabular}

$\mathrm{FR}=$ treatment with a $25 \%$ of forage rape inclusion in the diet; $\mathrm{ST}=$ treatment with a $25 \%$ of summer turnip inclusion in the diet; $\mathrm{PCV}=$ packed red cell volume; $\mathrm{RBC}=$ red blood cell; $\mathrm{WBC}=$ white blood cell; $\mathrm{MCV}=$ mean corpuscular volume; $\mathrm{MCHC}=$ mean corpuscular haemoglobin concentration; GGT = gamma-glutamyl transpeptidase; $\mathrm{T} 3=$ triiodothyronine; $\mathrm{ND}=$ not detected.

\section{Discussion}

\section{Intake, performance and milk composition}

Total DM intake was reduced in cows receiving either ST or FR, due to a lower DMI of 3.1 and $3.3 \mathrm{~kg}$ DM (for FR and ST, respectively) out of the $5 \mathrm{~kg}$ DM of brassica that were offered to replace the silage and concentrate from the control diet. This finding is similar to that from Moate et al. (1998), who reported a reduction in DMI when lactating dairy cows were supplemented with ST. The reduction in voluntary DMI may be attributed to physical limitations for ingestion due to the high water content and bulkiness of brassicas that increase the fresh weight that cows have to ingest, and therefore affects DMI (Stefanski et al., 2010). For example, compared to the control diet, the fresh weight intake amounts increased by 16.1 and $23.3 \mathrm{~kg}$ for cows supplemented with FR and ST, respectively. Cows supplemented with ST spent 46 and 98 more min eating (in $11 \mathrm{~h}$ of observation; data not shown) compared to cows offered the FR and control diets, respectively. In contrast, cows ruminating time was 42 and 61 min longer for cows fed the control diet compared to those in the FR and ST groups, respectively.

Estimated ME (54.9, 53.1 and $52.9 \mathrm{Mcal} /$ day for control, FR and ST, respectively) and CP intakes (3.65, 3.84 and $3.71 \mathrm{~kg} /$ day for control, FR and ST, respectively) were similar across diets. Milk production levels observed in this study were around 24.1 and $24.3 \mathrm{~kg} / \mathrm{day}$. According to AFRC (1995), ME and protein allowable milk production for a $550 \mathrm{~kg}$ liveweight Holstein Friesian cow were 29 and $34 \mathrm{~kg}$ of milk/day, respectively (AFRC, 1995). Therefore, ME and CP intakes were not limiting milk production of these mid-lactation dairy cows.

The brassicas used in this study were representative of the characteristics previously described by others, namely high readily fermentable carbohydrates with low NDF $(<280 \mathrm{~g} / \mathrm{kg}$ DM) concentrations (Barry, 2013). These characteristics resulted in a greater NFC and lower NDF intake compared to the control diet, due to the partial replacement of grass silage with either ST or FR.

Moate et al. (1998) reported that replacing $3 \mathrm{~kg}$ of barley with $3 \mathrm{~kg}$ of ST did not affect milk production. Including $4.4 \mathrm{~kg}$ of ST instead of barley reduced milk production, whereas the combination of $2.8 \mathrm{~kg}$ of ST with a protein source (cottonseed meal or lupins), increased milk production (Moate et al., 1999). No changes in milk composition with ST supplementation have been reported in other studies (Moate et al., 1998 and 1999; Thomson et al., 2000). Williams et al. (2016) replaced $8.0 \mathrm{~kg}$ DM of lucerne cubes with FR and observed an increase in milk production $(+3.6 \mathrm{~kg} /$ day), without changes in milk composition.

\section{Rumen function}

Summer turnips and FR diets contained a greater concentration of NFC compared to the control diet. According to Keim et al. (2019), Barkant ST contains $82 \mathrm{~g} / \mathrm{kg}$ of starch compared to $59 \mathrm{~g} / \mathrm{kg}$ of starch in Spitfire FR (the cultivars used in this study) and more water soluble carbohydrates (144 v. $131 \mathrm{~g} / \mathrm{kg}$ DM; specifically sucrose, glucose and fructose). These differences in type and quantity of NFC are expected to modulate rumen fermentation (Oba, 2011) and might be responsible for the greater ISCFA and butyrate in the rumen of cows ( $6 \mathrm{~h}$ after supplementation) supplemented with ST. Cows supplemented with FR had greater acetate and lower propionate proportions in the rumen fluid, compared to the other two diets, resulting in greater Ac: Pr. The changes in SCFA molar proportions may be explained by lower starch concentrations in FR that did not compensate, as much as ST did, for the starch reduction associated with the reduction in grain-based concentrate in the diet of the cows in this study, since it is well known that fermentable starch increases propionate concentration and reduces $\mathrm{pH}$ in the rumen (Mohammed et al., 2010). Although mean ruminal 
$\mathrm{pH}$ was lower for cows supplemented with ST compared to the other dietary treatments, ruminal $\mathrm{pH}$ values were below 6.0 for $258 \mathrm{~min}$ per day but did not reach values below 5.8 at any time of the day, and therefore the risk of subclinical acidosis was considered minimal based on the accepted guidelines (Krause and Oetzel, 2006). This is in agreement with Keogh et al. (2009b) who found that when feeding $100 \%$ kale to pregnant dry dairy cows found that ruminal $\mathrm{pH}$ was not depressed below $\mathrm{pH}$ 6.1. The authors attributed this to the large bulk density of forage kale resulting in high levels of saliva production, thus buffering rumen $\mathrm{pH}$ which is similar to what was observed in this study

In contrast to our results, Sun et al. (2012) reported no differences in ISCFA and molar proportions of individual SCFAs in the rumen of sheep fed ST or FR. The contrast between the report of Sun et al. (2012) and our study might be explained by differences in fermentation pathways across animal species. For example, Muetzel et al. (2014) observed greater acetate and lower propionate concentrations in the rumen fluid from cattle compared to that of sheep and also reported donor species by feedstuff interactions on the molar proportions of acetate in in vitro batch-culture studies. Supplementation with both summer ST and FR reduced minor SCFA and $\mathrm{NH}_{3}$ concentrations in the rumen, which is consistent as these metabolites are produced in the rumen from deamination and decarboxylation processes from feed or microbial protein, and differences in branched chain SCFA concentrations probably reflect differences in one or both of these components (Liu et al., 2018). The difference in minor SCFA is in agreement with the greater MN observed with FR supplementation compared to the control diet. As rumen bacteria use $\mathrm{NH}_{3}$ nitrogen and branched chain SCFAs for their growth, therefore lowering $\mathrm{NH}_{3} \mathrm{~N}$ and branched chain SCFAs concentrations which is comparable to our study with greater MN (Roman-Garcia et al., 2016). The greater MN when supplementing FR may be due to better energy supply in the rumen because of its high DM degradation rate (Keim et al., 2019) or due to changes in microbial communities. For example, Sun et al. (2015) reported that feeding FR to lambs modified bacterial communities in the rumen compared to ryegrass-fed animals. They observed greater protozoal cell numbers in the rumen of lambs fed FR. This increase might be in agreement with the greater MN observed in our study, as protozoa can represent from $10 \%$ to $30 \%$ (rarely exceeding $20 \%$ ) of MN to the small intestine (Sok et al., 2017) and the technique we used to estimate MN (PDs; Supplementary Material S3) also considers protozoa. The greater MN in cows supplemented with FR did not result in greater milk protein concentration or protein yield. This might be due to a surplus in the supply of amino acids to the mammary gland relative to the animal's demands, as it is required that cows have the genetic merit to produce more milk protein (Chagunda et al., 2009). The postulated excess in amino acids relative to the requirements may also provide an explanation for the similar blood and milk urea concentrations observed in the three dietary treatments, despite the lower ruminal $\mathrm{NH}_{3}$ concentrations measured in this study. Lower $\mathrm{NH}_{3}$ concentrations in the rumen would be expected to have resulted in lower plasma urea concentrations (Lapierre et al., 2005), and these be accompanied by lower milk urea concentrations (Pacheco and Waghorn, 2008). However, amino acids that are surplus to requirements will be catabolized and contribute to the urea pool. Also, the efficiency of transfer of absorbed amino acids into milk protein decreases with increasing supply of protein and is linked directly with increased hepatic removal of amino acids (Lapierre et al., 2005 and 2006).

\section{Haematological measures}

Secondary compounds in brassicas, such as glucosinolates and SMCO, can produce nutritional and health disorders (Keogh et al., 2009b). For example, Coxganser et al. (1994) observed increased Heinz-Ehrlich body counts on RBCS (which are associated with anaemia and depressed DMI), lower PCV and altered thyroid function in lambs grazing brassicas. Furthermore, Collett et al. (2014) stated that some nitrile derivatives of glucosinolates from ST and FR can be hepatotoxic. However, in our study no Heinz-Ehrlich bodies were observed, and there were no differences for any of the blood parameters suggesting that at the level of inclusion we used, supplementation with summer ST and FR does not cause anaemia, liver damage or altered thyroid function.

The fact that supplementation with summer ST and FR did not decrease milk production and milk composition is an advantage for dairy farmers. These crops may increase farm profitability and allow increases in the feeding budget (due to their greater DM yields than grass) and promote diversity of the feed base used. The replacement of grass silage and commercial concentrates with brassicas reduces feeding costs. Garcia et al. (2008) reported that growing crops on-farm helps to reduce the need for purchased supplements and, therefore, reduces production costs and increases profitability.

These results indicate that mid-lactation dairy cows fed with brassicas are able to maintain production despite the reduced intake, probably due to improved rumen fermentation and nutrient utilization.

\section{Acknowledgements}

This research was funded by the Chilean National Fund for Science and Technology (FONDECYT), Project code 11150538.

(1) 0. Balocchi 0000-0003-1664-783X

(D) R. Pulido 0000-0002-7107-8054

P. Sepúlveda-Varas 0000-0003-3349-0977

D. Pacheco 0000-0002-9307-9197

(D) J. P. Keim 0000-0003-4277-6491

\section{Declaration of interest}

All authors declare no conflicts of interest.

\section{Ethics statement}

All experimental procedures were approved by the Universidad Austral Institutional Animal Care and Use Committee (Approval Number: 237/2015). 


\section{Software and data repository resources}

If requested, data can be provided via e-mail by the corresponding author.

\section{Supplementary material}

To view supplementary material for this article, please visit https://doi.org/10.1017/S175173112000021X

\section{References}

AFRC 1995. Energy and protein requirements of ruminants. AFRC technical committee on response to nutrients. CAB International, Wallingford, Oxon, UK. Association of Official Analytical Chemists 1996. Official methods of analysis, 16th edition. AOAC, Washington, DC, USA.

Barry TN 2013. The feeding value of forage brassica plants for grazing ruminant livestock. Animal Feed Science and Technology 181, 15-25.

Chagunda MGG, Romer DAM and Roberts DJ 2009. Effect of genotype and feeding regime on enteric methane, non-milk nitrogen and performance of dairy cows during the winter feeding period. Livestock Science 122, 323-332.

Collett MG, Stegelmeier BL and Tapper BA 2014. Could nitrile derivatives of Turnip (Brassica rapa) glucosinolates be hepato- or cholangiotoxic in cattle? Journal of Agricultural and Food Chemistry 62, 7370-7375.

Cosgrove GP, Jonker A, Lowe KA, Taylor PS and Pacheco D 2017. Diurnal variation in urine nitrogen and creatinine concentrations from lactating cows grazing ryegrass-dominant pasture in autumn and late spring-summer. Animal Production Science 57, 1297-1304.

Coxganser JM, Jung GA, Pushkin RT and Reid RL 1994. Evaluation of brassicas in grazing systems for sheep: II. Blood composition and nutrient status. Journal of Animal Science 72, 1832-1841.

Garcia SC, Fulkerson WJ and Brookes SU 2008. Dry matter production, nutritive value and efficiency of nutrient utilization of a complementary forage rotation compared to a grass pasture system. Grass and Forage Science 63, 284-300.

Keim JP, Cabanilla J, Balocchi OA, Pulido RG and Bertrand A 2019. In vitro fermentation and in situ rumen degradation kinetics of summer forage brassica plants. Animal Production Science 59, 1271-1280.

Keogh B, French P, McGrath T, Storey T and Mulligan FJ 2009a. Comparison of the performance of dairy cows offered kale, swedes and perennial ryegrass herbage in situ and perennial ryegrass silage fed indoors in late pregnancy during winter in Ireland. Grass and Forage Science 64, 49-56.

Keogh B, French P, Murphy JJ, Mee JF, McGrath T, Storey T, Grant J and Mulligan FJ 2009b. A note on the effect of dietary proportions of kale (Brassica oleracea) and grass silage on rumen $\mathrm{pH}$ and volatile fatty acid concentrations in dry dairy cows. Livestock Science 126, 302-305.

Krause KM and Oetzel GR 2006. Understanding and preventing subacute ruminal acidosis in dairy herds: A review. Animal Feed Science and Technology 126, 215-236.

Lambert MG, Abrams SM, Harpster HW and Jung GA 1987. Effect of hay substitution on intake and digestibility of forage rape (Brassica Napus) fed to lambs. Journal of Animal Science 65, 1639-1646.

Lapierre H, Berthiaume R, Raggio G, Thivierge MC, Doepel L, Pacheco D, Dubreuil $P$ and Lobley GE 2005. The route of absorbed nitrogen into milk protein Animal Science 80, 11-22.

Lapierre H, Pacheco D, Berthiaume R, Ouellet DR, Schwab CG, Dubreuil P, Holtrop $\mathrm{G}$ and Lobley GE 2006. What is the true supply of amino acids for a dairy cow? Journal of Dairy Science 89, E1-E14.

Lindberg JE 1989. Nitrogen-metabolism and urinary-excretion of purines in goat kids. British Journal of Nutrition 61, 309-321.

Liu Q, Wang C, Guo G, Huo WJ, Zhang SL, Pei CX, Zhang YL and Wang H 2018. Effects of branched-chain volatile fatty acids on lactation performance and mRNA expression of genes related to fatty acid synthesis in mammary gland of dairy cows. Animal 12, 2071-2079.

Makkar HPS 2004. Development, standardization and validation of nuclear based technologies for estimating microbial protein supply in ruminant livestock for improving productivity, In Estimation of microbial protein supply in ruminants using urinary purine derivatives (ed. HPS Makkar and XB Chen), pp. 1-15 Springer Science+Business Media, Dordrecht, the Netherlands.

Moate PJ, Dalley DE, Martin K and Grainger C 1998. Milk production responses to turnips fed to dairy cows in mid lactation. Australian Journal of Experimental Agriculture 38, 117-123.

Moate PJ, Dalley DE, Roche JR, Grainger C, Hannah M and Martin K 1999. Turnips and protein supplements for lactating dairy cows. Australian Journal of Experimental Agriculture 39, 389-400.

Mohammed R, Kennelly JJ, Kramer JK, Beauchemin KA, Stanton CS and Murphy JJ 2010. Effect of grain type and processing method on rumen fermentation and milk rumenic acid production. Animal 4, 1425-1444.

Muetzel S, Hunt C and Tavendale MH 2014. A fully automated incubation system for the measurement of gas production and gas composition. Animal Feed Science and Technology 196, 1-11.

Oba M 2011. Review: Effects of feeding sugars on productivity of lactating dairy cows. Canadian Journal of Animal Science 91, 37-46.

Pacheco D and Waghorn GC 2008. Dietary nitrogen - definitions, digestion, excretion and consequences of excess for grazing ruminants. Proceedings of the New Zealand Grassland Association 70, 107-116.

Poff JA, Balocchi OA and Lopez IF 2011. Sward and tiller growth dynamics of Lolium perenne $\mathrm{L}$. as affected by defoliation frequency during autumn. Crop \& Pasture Science 62, 346-354.

Roman-Garcia Y, White RR and Firkins JL 2016. Meta-analysis of postruminal microbial nitrogen flows in dairy cattle. I. Derivation of equations. Journal of Dairy Science 99, 7918-7931.

Singh M, Sharma K, Dutta N, Singh P, Verma AK and Mehra UR 2007. Estimation of rumen microbial protein supply using urinary purine derivatives excretion in crossbred calves fed at different levels of feed intake. Asian-Australasian Journal of Animal Sciences 20, 1567-1574.

Sok M, Ouellet DR, Firkins JL, Pellerin D and Lapierre H 2017. Amino acid composition of rumen bacteria and protozoa in cattle. Journal of Dairy Science 10, 5241-5249.

Stefanski EP, Garcia SC, Farina SR, Tan DKY and Tanner D 2010. Effects of sowing rate and grazing management of forage rape (Brassica napus) on grazing behaviour and utilisation by dairy cattle. Animal Production Science 50, 560-567.

Sun XZ, Henderson G, Cox F, Molano G, Harrison SJ, Luo D, Janssen PH and Pacheco D 2015. Lambs fed fresh winter forage rape (Brassica napus L.) emit less methane than those fed perennial ryegrass (Lolium perenne L.), and possible mechanisms behind the difference. PLOS ONE 10, e0119697.

Sun XZ, Waghorn GC, Hoskin SO, Harrison SJ, Muetzel S and Pacheco D 2012. Methane emissions from sheep fed fresh brassicas (Brassica spp.) compared to perennial ryegrass (Lolium perenne). Animal Feed Science and Technology 176, 107-116.

Tavendale MH, Meagher LP, Pacheco D, Walker N, Attwood GT and Subathira S 2005. Methane production from in vitro rumen incubations with Lotus pedunculatus and Medicago sativa, and effects of extractable condensed tannin fractions on methanogenesis. Animal Feed Science and Technology 123, 403-419. Thomson NA, Clark DA, Waugh CD, van der Poel WC and MacGibbon AKH 2000. Effect on milk characteristics to supplementing cows on a restricted pasture allowance with different amounts of either turnips or sorghum. Proceedings of the New Zealand Society of Animal Production 60, 320-323.

Tilley JMA and Terry RA 1963. A two-stage technique for the in vitro digestion of forage crops. Grass and Forage Science 18, 104-111.

Van Soest PJ, Robertson JB and Lewis BA 1991. Methods for dietary fiber, neutra detergent fiber, and nonstarch polysaccharides in relation to animal nutrition. Journal of Dairy Science 74, 3583-3597.

Weatherburn M 1967. Phenol-hypochlorite reaction for determination of ammonia. Analytical Chemistry 39, 971-974.

Westwood CT and Mulcock H 2012. Nutritional evaluation of five species of forage brassica. Proceedings of the New Zealand Grassland Association 74, 31-38. Williams SRO, Moate PJ, Deighton MH, Hannah MC, Wales WJ and Jacobs JL 2016. Milk production and composition, and methane emissions from dairy cows fed lucerne hay with forage brassica or chicory. Animal Production Science 56, 304-311. Yanez-Ruiz DR, Bannink A, Dijkstra J, Kebreab E, Morgavi DP, O'Kiely P, Reynolds CK, Schwarm A, Shingfield KJ, Yu Z and Hristov AN 2016. Design, implementation and interpretation of in vitro batch culture experiments to assess enteric methane mitigation in ruminants-a review. Animal Feed Science and Technology 216, 1-18. 